\title{
MucoAdHesion: A NeW POLYMERIC APPROACH
}

\author{
Navneet Nagpal ${ }^{1 *}$, Jaideep Bajaj ${ }^{2}$, Garima Saini $^{1}$, Lovepreet Kaur ${ }^{1}$, Karan Sharma ${ }^{1}$ and \\ Manisha Arora ${ }^{3}$ \\ ${ }^{1}$ Department of Pharmaceutics, ${ }^{2}$ Department of Pharmacology, ${ }^{3}$ Department of Pharmaceutical Chemistry, \\ Khalsa College of Pharmacy, Amritsar 143001, Punjab, India \\ ${ }^{*}$ E-mail: n.nagpal721@gmail.com \\ Tel.: +919316849394.
}

Received: May 08, 2016 / Revised: Jul 30, 2016 / Accepted: Sep 04, 2016

\begin{abstract}
Bioadhesion is the ability of a material to adhere to a biological tissue for an extended period of time. In the case of polymer attached to the mucin layer of a mucosal tissue, the term mucoahesion is used. Mucoadhesion occurs between two surfaces, one of which is a mucous membrane and another is drug delivery system. It gives rapid absorption and increased bioavailability. Mucoadhesive drug delivery systems have been developed for various routes for both systemic and local effects. Mucoadhesive as a controlled drug delivery system have been developed to increase gastric retention time of the dosage forms. This review article aims to provide an overview of the various aspects of mucoadhesion and mucoadhesive materials.
\end{abstract}

Key words: Bioadhesion, Buccal, Gastric, Mucoadhesion, Polymers.

\section{INTRODUCTION}

The approach of mucoadhesive drug delivery system had been arised in early 1980 (Boddupalli et al 2010). Adhesion can be defined as the bond produced by contact between a pressure sensitive adhesive and a surface. When the biological substrate is a mucosal layer than the phenomena is known as mucoadhesion (Muthukumaran et al 2011). Mucoadhesive drug delivery systems prolong the residence time of the dosage form at the site of application or absorption (Ahuja et al 1997). Mucoadhesion process occurs in polymeric drug delivery system which is a complex process (wetting, adsorption, chemical bonding etc); and is mainly influenced by polymeric based properties like degree of cross linking, chain length, and various functional groups in polymer structure. Mucoadhesive systems have been widely used throughout many mucosal covered organelles for the delivery of active ingredients at the site of action (Woertz et al 2013). Mucoadhesion keeps the delivery system adhering to the mucus membrane, which remain in close contact with the absorption tissue, releasing the drug at the site of action leading to an increase in bioavailability (Mythri et al 2011). Since adhesion of an adhesive to a biological system is a type of bioadhesion in which water soluble or water insoluble polymer used with therapeutic agents; mucoadhesive drug delivery systems have been developed for oral, buccal, nasal, rectal and vaginal routes for both systemic and local effects (Alexander et al 2011).

Benefits of mucoadhesive drug delivery system

Mucoadhesive drug delivery system has several benefits which are as follows:

Prolongs the residence time of the dosage form at the site of absorption, hence increases the bioavailability (Asane, 2007; Krupashree et al 2014; Bhalodia et al 2010; Hagerstorm et al 2003).

- Excellent accessibility

- Rapid onset of action possible

- Rapid absorption because of enormous blood supply and good perfusion rates 
- An alternative to oral route, where by the drug is protected from degradation in the acidic environment of the GIT

- Better patient compliance-ease of drug administration

- Rapid cellular recovery and healing of the local site

- Reduced dosing frequency

- Shorter treatment period

- Increased safety margin of high potency drugs due to better control of plasma levels, maximum utilization of drug enabling reduction in total amount of drug administered

- Faster onset of action is achieved due to mucosal surface

- Drugs which are unstable in the acidic environment are destroyed by enzymatic or alkaline environment of intestine can be administered by this route. e.g. Buccal sublingual

- The buccal mucosa is highly perfused with blood vessels and offers a greater permeability than the skin.

\section{Limitations of mucoadhesive drug delivery system}

Drugs which irritate the oral mucosa, have a bitter or unpleasant taste, odour, cannot be administered by this route (Chowdary and Srinivas, 2000; Clark et al 2000; Nielsen et al 1998).

- Drugs, which are unstable at buccal pH, cannot be administered by this route

- Only drugs with small dose requirements can be administered

- Only those drugs, which are absorbed by passive diffusion, can be administered by this route

- Eating and drinking may become restricted

- In case of vaginal delivery, the drug has to be stable in the acidic vaginal $\mathrm{pH}$

- In case of ocular formulations, the formulation may cause uneasiness and blurring

- It may get dislodged

- In case of nasal formulations, the presence of the formulation may stimulate sneezing and subsequent dislodgement of the formulation

- The formulation may irritate the sensitive nasal mucosa

- Over hydration may lead to the formation of slippery surface and structural integrity of the formulation may get disrupted by the swelling and hydration of the bioadhesive polymers

- Swallowing of the formulation by the patient may be possible

\section{Factors affecting mucoadhesive drug delivery system \\ Polymer related factors \\ Molecular weight}

With the increase in the molecular weight (MW) of the polymer chain, the mucoadhesiveness of a polymer significantly increases. (Saraswathi et al 2013).

\section{Chain length}

With the increase in the chain length of the polymers there is an increase in the mucoadhesive property of the polymer (Raghavendra Rao et al 2013).

\section{Spatial arrangement}

Spatial conformation of a molecule is also important factor. Besides molecular weight or chain length, spatial conformation of a molecule is also important. The helical conformation of dextran may shield many adhesively active groups primarily responsible for adhesion, unlike PEG polymers which have a linear confirmation.

\section{Flexibility}

Flexible polymer chains help in the better penetration and entanglement of the polymer chains with that of mucosal layer thereby improving the bioadhesive property. The flexibility of the polymer chains is generally affected by the crosslinking reactions and the hydration of the polymer network. Higher the crosslinking density, lower is the flexibility of the polymer chains (Khan et al 2016).

\section{Hydration of polymer}

In addition to the reduced flexibility of the polymer chains, crosslinking results in the reduced diffusion of water into the crosslinked polymer matrix. Hence highly crosslinked polymeric matrix limits the interpenetration of polymer and mucin chains amongst themselves which in turn results in the decrease in the mucoadhesive strength.

\section{Hydrogen bonding}

In general, stronger the hydrogen bonding stronger is the adhesion. The functional groups responsible for such kind of interaction include 
hydroxyl, carboxyl and amino groups (Asane, 2007).

\section{Charge and degree of ionization of polymer}

The presence of charged functional groups in the polymer chain has a marked effect on the strength of the bioadhesion. Anionic polyelectrolytes have been found to form stronger adhesion when compared with neutral polymers.

\section{Polymer concentration}

In general, polymer concentration in the range of 1-2.5 wt \% may exhibit sufficient mucoadhesive property for biomedical applications.

\section{Environmental factors}

Apart from the above-mentioned physicochemical properties of the polymeric network, various environmental factors also play an important role in mucoadhesion.

\section{$p H$}

Some studies have shown that the $\mathrm{pH}$ of the medium is important for the degree of hydration of cross link (Ahuja et al 1997; Carvalho et al 2010)

\section{Applied strength}

The pressure initially applied to the mucoadhesive tissue contact site can affect the depth of interpenetration. If high pressure is applied for a satisfactory longer period of time, polymers may become mucoadhesive even though they do not have attractive interaction with mucins.

\section{Contact time}

With the initial increase in the contact time there is an increase in the hydration of the polymer matrix and subsequent interpenetration of the polymer chains. The physiology of the mucosal layer may vary depending on the pathophysiological nature of the human body.

\section{Swelling}

Swelling depends both on polymer concentration and on water presence. When swelling is too great, decrease in bioadhesion.

\section{Physiological factors}

The physiological factors which play an important role in governing the mucoadhesive property of a polymer matrix include texture and thickness of mucosa.

\section{Mucin turnover}

The mucin turnover is expected to limit the residence time of the mucoadhesive on the mucus layer. No matter how high the mucoadhesive strength is.

\section{Disease state}

The physicochemical properties of the mucus are known to change during disease conditions such as common cold, gastric ulcers, ulcerative colitis, etc.

\section{Mucous membranes}

Mucous membrane or Mucosae is the layer of connective tissue (the lamina propria) having moist surface which is responsible for lining the walls of various body cavities such as the gastrointestinal and respiratory tracts.

\section{Composition of mucus layer}

Mucus is translucent and viscous secretion which forms a thin, continuous gel layer sticking to the mucosal epithelial surface. Mucus glycoprotiens are high molecular weight proteins possessing attached oligosaccharide units containing, L-fucose, D-galactose, $\mathrm{N}$-acetylD-glucosamine, $N$-acetyl-D-galactosamine and sialic acid (Andrews et al 2009).

\section{Functions of mucous layer}

Mucous layer is protective because of its hydrophobicity. It influences the bioavailability of drugs as it acts as a barrier in tissue absorption of drugs and other substrates. It strongly bonds with the epithelial cell surface as a continuous gel layer. It plays a major role in the lubrication of the mucosal membrane and maintenance of its moisture.

\section{Mechanism of mucoadhesion}

The mechanism of mucoadhesion is generally divided into two steps: the contact stage and the consolidation stage. The first stage is characterized by the contact between the mucoadhesive and the mucus membrane, with spreading and swelling of the formulation, initiating its deep contact with the mucus layer. In the consolidation step, the mucoadhesive materials are activated by the presence of moisture.

Moisture plasticizes the system, allowing the mucoadhesive molecules to break free and to link up by weak Vander-Waals and hydrogen bonds. Figure 1 depicts the schematics of mucoadhesive mechanism. 


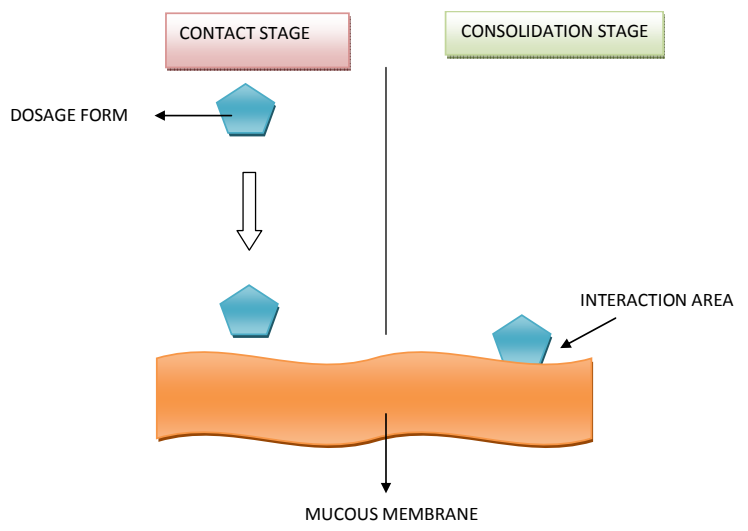

Fig. 1. Mechanism of mucoadhesive drug delivery system

\section{Mucoadhesive polymers}

Mucoadhesive delivery systems are being explored for the localization of the active agents to a particular location/site (Eouani et al 2001). Polymers have played an important role in designing such systems in order to increase the residence time of the active agent at the desired location. Mucoadhesive polymers are watersoluble and water insoluble polymers (Dharmendra et al 2012). They attach to mucus or the cell membrane by various interactions such as hydrogen bonding and hydrophobic or electrostatic interactions. An ideal mucoadhesive polymer has following characteristics.

- It should be non-toxic and non-absorbable from GIT

- Non-irritant to mucous membrane.

- Form a strong non covalent bond with mucin epithelial cell surfaces

- It should adhere quickly to moist tissue and should possess site specificity

- Allow easy incorporation of the drug and offer no hindrance to its release

- Polymer must not decompose on storage or during shelf life of dosage form

- $\quad$ Cost effective

Mucoahesive polymers are classified as follows:

\section{Hydrophilic polymers}

These categories of polymers are soluble in water which swell when put into an aqueous media with subsequent dissolution of the matrix. It contains carboxylic group and possess excellent mucoadhesive properties. These polymers are also directly compressed with the drugs to get an excellent mucoadhesive delivery system. These are poly vinyl pyrrolidone (PVP), Methyl cellulose (MC), Sodium carboxy methylcellulose (SCMC), Hydroxy propyl cellulose (HPC), Xantham gum and other cellulose derivative.

\section{Hydrogels}

These are three-dimensionally cross-linked polymer chains which have the ability to hold water within its porous structure and swell by means of adhesion with the mucus that covers epithelia. The water holding capacity of the hydrogels is mainly due to the presence of hydrophilic functional groups like hydroxyl, amino and carboxyl groups. Hydrogels are further classified in to sub categories on the basis of their charge and on the basis of their source.

On the basis of charge, hydrogels are classified into following categories:

\section{Anionic polymers}

Carbopol, Polyacrylates.

\section{Cationic polymers}

Chitosan

\section{Neutral/non-ionic polymers}

Eudragit analogues (Carvalho et al 2010)

On the basis of source hydrogels are classified into following categories:

\section{Synthetic polymers}

Cellulose derivatives, Carbopols etc.

\section{Natural polymers}

Tragacanth, Pectin, Gelatin, Sodium alginate, Acacia.

\section{Second generation polymers}

These are modified polymers; least effected by mucus turnover rates and is site specific. They are further divided in to two sub categories as follows:

\section{Thiolated polymers}

These having thiol group, known as thiomers. Thiomers are capable of forming intra-and inter chain di-sulphide bonds within the polymeric network leading to strongly improved cohesive properties and stability of drug delivery systems such as matrix tablets. e.g. chitosaniminothiolane, poly(acrylicacid)-cysteine, poly(acrylicacid)-homocysteine, chitosanthioglycolic acid, chitosan-thioethylamidine, alginate-cysteine, poly(methacrylic acid)- 
cysteine and sodium carboxymethylcellulosecysteine.

\section{Polymers containing lecithin}

These naturally occurring proteins results in biological recognition phenomena involving cells and proteins. After binding to the cell the lecithin may either remain on the cell surface or may be taken inside the cell via endocytosis. These types of polymers results in site specific as well as control drug delivery system. Lecithin extracted from legumes has been widely explored for targeted delivery systems.

\section{Third generation polymers Polyox WSR}

A class of high molecular weight polyethylene molecular weight polyethylene oxide homo- polymers having the following properties:

- Water soluble hydrophilic nature

- Functional group for hydrogen bonding

- Biocompatible and non toxic

- High molecular weight

\section{Novel mucoadhesive polymers}

- A new class of hydrophilic pressure sensitive adhesives (PSA) has been developed by corium technologies. Complex have been prepared by non covalent hydrogen bonding cross linking of a film forming hydrophilic polymer with a short chain plasticizer having reactive $\mathrm{OH}$ groups at chain ends.

- Tomato lectin showed that it has binding selectivity to the small intestine epithelium

Table 1 summarizes important information about some of the widely used mucoadhesive polymers and their applications.

Table 1. Example of polymers used in mucoadhesive drug delivery system

\begin{tabular}{|c|c|c|c|c|c|}
\hline $\begin{array}{c}\text { S. } \\
\text { No. }\end{array}$ & $\begin{array}{l}\text { Name of } \\
\text { polymer }\end{array}$ & $\begin{array}{c}\text { Molecular } \\
\text { weight }\end{array}$ & Description & Application & Reference \\
\hline 1 & $\begin{array}{l}\text { Polyvinyl } \\
\text { pyrolidine }\end{array}$ & $\begin{array}{c}2500- \\
3,000,000\end{array}$ & $\begin{array}{l}\text { White, odourless } \\
\text { And hygroscopic } \\
\text { powder }\end{array}$ & $\begin{array}{l}\text { Good emulsifying agent, } \\
\text { thickening agent, binding } \\
\text { agent }\end{array}$ & $\begin{array}{l}\text { (Fikentscher and } \\
\text { Herrle, 1945) }\end{array}$ \\
\hline 2 & Carbopol & $\begin{array}{c}7 \times 10^{5} \text { to } \\
4 \times 10^{9}\end{array}$ & $\begin{array}{c}\text { White, fluffy, acidic, } \\
\text { hygroscopic powder } \\
\text { with slight } \\
\text { characteristics } \\
\text { odour }\end{array}$ & $\begin{array}{l}\text { Excellent thickening, } \\
\text { emulsifying, gelling, binding } \\
\text { agent, possess good } \\
\text { bioadhesive strength }\end{array}$ & $\begin{array}{l}\text { (Efentakis and } \\
\text { Peponaki, 2008) }\end{array}$ \\
\hline 3 & $\begin{array}{l}\text { Sodium } \\
\text { carboxy } \\
\text { methyl } \\
\text { cellulose } \\
\end{array}$ & $\begin{array}{l}90,000- \\
70,000\end{array}$ & $\begin{array}{l}\text { White to fainty } \\
\text { yellow, odourless, } \\
\text { hygroscopic powder }\end{array}$ & $\begin{array}{l}\text { As emulsifying, gelling, and } \\
\text { binding agent, possess good } \\
\text { bioadhesive strength }\end{array}$ & $\begin{array}{c}\text { (Oza and Frank, } \\
\text { 1986) }\end{array}$ \\
\hline 4 & $\begin{array}{l}\text { Methyl } \\
\text { cellulose }\end{array}$ & $\begin{array}{c}10,000- \\
220,000 \mathrm{Da}\end{array}$ & $\begin{array}{c}\text { White, fibrous } \\
\text { powder or granules. } \\
\text { It is odorless and } \\
\text { tasteless }\end{array}$ & $\begin{array}{l}\text { It is used in oral and topical } \\
\text { pharmaceutical formulation } \\
\text { and used in disintegrant. }\end{array}$ & $\begin{array}{l}\text { (Suchaoin et al } \\
\text { 2016) }\end{array}$ \\
\hline 5. & $\begin{array}{l}\text { Hydroxy } \\
\text { propyl } \\
\text { cellulose }\end{array}$ & $\begin{array}{c}60,000- \\
1,000,000\end{array}$ & $\begin{array}{c}\text { White to slightly } \\
\text { yellowish,odourless } \\
\text { powder. }\end{array}$ & $\begin{array}{l}\text { It is used as a thickening } \\
\text { agent, emulision stabilizer, } \\
\text { and suspending agent in } \\
\text { oral. }\end{array}$ & (Satoh et al 1989) \\
\hline 6. & Chitosan & $\begin{array}{c}10,000- \\
1,000,000\end{array}$ & $\begin{array}{l}\text { Odorless, white or } \\
\text { creamy-white } \\
\text { powder or flakes }\end{array}$ & $\begin{array}{l}\text { It is used in cosmetics and } \\
\text { pharmaceutical } \\
\text { formulations and used as a } \\
\text { compoment of } \\
\text { mucoadhesive dosage form, } \\
\text { flims, gels, tablet and beads }\end{array}$ & (Dutta et al 2004) \\
\hline 7. & $\begin{array}{l}\text { Eudragit } \\
\text { analogue }\end{array}$ & 47,000 & $\begin{array}{c}\text { Transparent or pale } \\
\text { yellowish colour, } \\
\text { odourless }\end{array}$ & $\begin{array}{l}\text { Good Emulsifying agent, } \\
\text { binding agent }\end{array}$ & (Singh et al 2010) \\
\hline 8. & $\begin{array}{l}\text { Sodiun } \\
\text { alginate }\end{array}$ & 220,000 & $\begin{array}{c}\text { Odorless and } \\
\text { tasteless, white to }\end{array}$ & $\begin{array}{l}\text { It is used as a stabilizer in } \\
\text { emulsions, as a suspending }\end{array}$ & $\begin{array}{l}\text { (Tonnesen and } \\
\text { Karlsen, 2002) }\end{array}$ \\
\hline
\end{tabular}




\begin{tabular}{|c|c|c|c|c|c|}
\hline 9. & Tragacanth & $\begin{array}{c}\text { yellowish-brown } \\
\text { colored powder } \\
\text { Flattened, } \\
\text { lamellated,frequentl } \\
\text { y curved fragments } \\
\text { and white to } \\
\text { yellowish in color, } \\
\text { odourless. }\end{array}$ & $\begin{array}{c}\text { agent, tablet disintegrant } \\
\text { and tablet binder }\end{array}$ & $\begin{array}{c}\text { Emulsifying and suspending } \\
\text { agent in a varity of } \\
\text { pharmaceutical } \\
\text { formulations. It is used in } \\
\text { creams and gels. }\end{array}$ \\
\hline 10. & Gelatin & $\begin{array}{c}\text { Light-amber to } \\
\text { faintly yellow } \\
\text { colored, vitreous, } \\
\text { brittle solid or as a } \\
\text { coarse powder }\end{array}$ & $\begin{array}{c}\text { It is used as oral } \\
\text { administration hard and } \\
\text { soft gelatin capsules }\end{array}$ & (Fattahi et al 2013) \\
\hline 11. & $\begin{array}{c}\text { Xanthum } \\
\text { gum }\end{array}$ & $1,000,0000$ & $\begin{array}{c}\text { Cream on ond Dash, } \\
\text { colored, odourless, } \\
\text { free flowing, fine } \\
\text { powder }\end{array}$ & $\begin{array}{c}\text { It is used in oral and topical } \\
\text { pharmaceutical } \\
\text { formulation, cosmetics and } \\
\text { food as a suspending agent, } \\
\text { thickening agent and } \\
\text { emulsifiying agent }\end{array}$ & $\begin{array}{c}\text { (Phaechamud and } \\
\text { Ritthidej, 2008) }\end{array}$ \\
\hline
\end{tabular}

\section{Mucoadhesive dosage form Tablets}

Mucoadhesive tablets, in general, have the potential to be used for controlled release drug delivery, but coupling of mucoadhesive properties to tablet has additional advantages, for example, it offers efficient absorption and enhanced bioavailability of the drugs due to a high surface to volume ratio and facilitates a much more intimate contact with the mucus layer. Mucoadhesive tablets can adhere to any mucosal tissue including those found in stomach, thus offering the possibilities of localized as well as systemic controlled release of drugs. These are widely used because they offer prolonged release of drug from the dosage form, reduce frequency of drug administration and improve the patient compliance (Alur et al 1999).

\section{Buccal drug delivery system}

The presence of a smooth and relatively immobile surface for placement of a mucoadhesive tablet dosage form, the buccal region appears to be more suitable for sustained delivery of therapeutic agents using mucoadhesive systems. The buccal and sublingual routes avoid first-pass metabolism. These regions consist of a non-keratinized epithelium, resulting in a somewhat more permeable tissue than the skin. Therefore, drugs with a short biological half-life requiring a sustained release effect and exhibiting poor permeability, sensitivity to enzymatic degradation, or poor solubility may be good candidates to be delivered via the oral cavity. Relevant mucoadhesive dosage forms for the oral cavity include gels, patches, tablets, and ointments (Remunan-Lopez et al 1998).

\section{Gastrointestinal mucoadhesive drug delivery system}

It is the potential site for the long term in the development of mucoadhesive drug delivery system. This delivery system increase the drug plasma concentration and also therapeutic activity in order to increase the duration of drug stay in GIT (Surana and Kotecha, 2010).

Oral route is most favored route of administration, but hepatic first-pass metabolism, degradation of drug during absorption, mucus covering GI epithelia, and high turnover of mucus are serious concerns of oral route. In recent years, the gastrointestinal tract (GIT) delivery emerged as a most important route of administration.

\section{Films}

Mucoadhesive films may be preferred over adhesive tablets in terms of flexibility and comfort. In addition, they can circumvent the relatively short residence time of oral gels on the mucosa, which are easily washed away and removed by saliva. Moreover, in the case of local delivery for oral diseases, the films also help to protect the wound surface, thus helping to reduce pain, and treat the disease more effectively. An ideal film should be flexible, elastic, and soft, yet adequately strong to withstand breakage due to stress from mouth movements. It must also possess good mucoadhesive strength in order to be retained in the mouth for the desired duration of action. Swelling of film should not be too extensive in order to prevent discomfort (Shah et al 2010). 


\section{Patches}

Patches are laminates consisting of an impermeable backing layer, a drug-containing reservoir layer from which the drug is released in a controlled manner, and a mucoadhesive surface for mucosal attachment. Patch systems are similar to those used in transdermal drug delivery. Two methods used to prepare adhesive patches include solvent casting and direct milling. In the solvent casting method, the intermediate sheet from which patches are punched is prepared by casting the solution of the drug and polymers onto a backing layer sheet, and subsequently allowing the solvents to evaporate. In the direct milling method, formulation constituents are homogeneously mixed and compressed to the desired thickness, and patches of predetermined size and shape are then cut or punched out. An impermeable backing layer may also be applied to control the direction of drug release, prevent drug loss, and minimize deformation and disintegration of the device during the application period (Gibson et al 2007).

\section{Gels and ointments}

Semisolid dosage forms, such as gels and ointments, have the advantage of easy dispersion throughout the oral mucosa. However, drug dosing from semisolid dosage forms may not be as accurate as from tablets, patches, or films. Poor retention of the gels at the site of application has been overcome by using mucoadhesive formulations (Majithiya et al 2006). Certain mucoadhesive polymers, for example, sodium carboxymethylcellolose, carbopol, hyaluronic acid, and xanthan gum, undergo a phase change from liquid to semisolid. This change enhances the viscosity, which results in sustained and controlled release of drugs. Hydrogels are also a promising dosage form for buccal drug delivery. They are formed from polymers that are hydrated in an aqueous environment and physically entrap drug molecules for subsequent slow release by diffusion or erosion (Morimoto et al 1985). The application of mucoadhesive gels provides an extended retention time in the oral cavity, adequate drug penetration, as well as high efficacy and patient acceptability. A major application of adhesive gels is the local delivery of medicinal agents for the treatment of periodontitis, which is an inflammatory and infectious disease that causes formation of pockets between the gum and the tooth, and can eventually cause loss of teeth. It has been suggested that mucoadhesive polymers might be useful for periodontitis therapy when incorporated in antimicrobial-containing formulations that are easily introduced into the periodontal pocket with a syringe. HPMC has been used as an adhesive ointment ingredient. Additionally, a highly viscous gel was developed from carbopol and hydroxypropylcellulose for ointment dosage forms that could be maintained on the tissue for up to $8 \mathrm{~h}$ (Ishida et al 1983).

\section{Marketed products}

- Striant®, developed by Columbia Labs, is a testosterone extended-release buccal tablet that delivers testosterone systemically for hormone replacement in hypogonadal men

- Asftach ${ }^{\circledR}$ is a buccal tablet containing triamcinolone acetonide for treatment of apththous ulcers, and contains a bioadhesive layer and a dissolvable lactose nonadhesive backing layer

- DentiPatch ${ }^{\circledR}$ has been developed by Noven, which is a lidocaine extended-release buccal patch that adheres to the gingival tissue to provide for local analgesia, and was approved in the United States in May 1996

- $\quad$ Cydot ${ }^{\circledR}$ is an example of a patch technology where the patch adheres to the buccal mucosa for a period of up to $24 \mathrm{~h}$ to slowly release melatonin for normalizing circadian rhythms

- Metandren ${ }^{\circledR}$ is Methyltestosterone for buccal drug delivery to avoids first-pass hepatic metabolism (Ciba)

- Oreton ${ }^{\circledR}$, Schering Buccastem ${ }^{\circledR}$ contains prochlorperazine and is an alternative to enteral tablet (Table 2).

Table 2. Marketed gastroretentive products

\begin{tabular}{|c|c|c|}
\hline S. No. & Brand name & Active ingredient \\
\hline 1 & Cifran OD & Ciprofloxacin \\
\hline 2 & Madopar & Levodopa and benserazide \\
\hline 3 & Valrelease & Diazepam \\
\hline 4 & Topalkan & Aluminium-magnesium antacid \\
\hline 5 & Almagate & Flatcoat antacid \\
\hline 6 & Liquid & Gaviscon alginic acid and sodium bicarbonate \\
\hline
\end{tabular}




\section{CONCLUSION}

Mucoadhesive polymers may provide an important tool to improve the bioavailability of the active agent by improving the residence time at the delivery site. Development of novel mucoadhesive delivery systems are being undertaken so as to understand the various mechanism of mucoadhesion and improved permeation of active agents. Besides proven advantages such as mucoadhesion, an increase in the residence time of the polymer, penetration enhancement, and enzymatic inhibition; this class of polymers has enormous potential for the delivery of therapeutic macromolecules, genes, and vaccines thereby suggesting that

\section{REFERENCES}

Ahuja A, Khar RK, Ali J. Mucoadhesive drug delivery systems. Drug Dev. Ind. Pharm. 1997;23(5):489-515. [DOI: 10.3109/03639049709148498]

Alexander A, Ajazuddin, Tripathi DK, Verma T, Swarna, Maurya J, Patel S. Mechanism responsible for mucoadhesion of mucoadhesive drug delivery system: A review. Int. J. Appl. Biol. Pharm. Tech. 2011;2(1):434-45. [DOI: 10.5530/rjps.2014.4.2]

Alur HH, Pather SI, Mitra AK, Johnston TP. Transmucosal sustained-delivery of chlorpheniramine maleate in rabbits using a novel, natural mucoadhesive gum as an excipient in buccal tablets. Int. J. Pharm.1999;188(1):1-10. [DOI: 10.1016/S0378-5173(99)00211-2]

Andrews GP, Laverty TP, Jones DS. Mucoadhesive polymeric platforms for controlled drug delivery. Eur. J. Pharm. Biopharm. 2009;71(3):505-18. [DOI: 10.1016/j.ejpb.200 8.09.028]

Asane GS. Mucoadhesive gastro intestinal drug delivery system: An overview. Pharmainfo.net. 2007;5:1-5.

Basu B, Garala K, Thimmasetty J. Formulation and evaluation of pimozide buccal mucoadhesive patches. Int. J. Pharm. Sci. Nanotechnol. 2010;2(4):739-47.

Bhalodia R, Basu B, Garala K, Joshi B, Mehta K. Buccoadhesive drug delivery systems: A review. Int. J. Pharm. Bio Sci. 2010;1(2):1-32.

Bobade NN, Atram SC, Wankhade VP, Pande SD, Tapar KK. A review on buccal drug delivery system. Int. J. Pharm. Pharm. Sci. Res. 2013;3(1):35-40.

Boddupalli BM, Mohammed ZNK, Nath RA, Banji D. Mucoadhesive drug delivery system: An overview. J. Adv. Pharm. Technol. Res. 2010;1(4):381-7. [DOI: 10.4103/011 0-5558.76436]

Carvalho FC, Bruschi ML, Evangelista RC, Gremião MPD. Mucoadhesive drug delivery systems. Braz. J. Pharm. Sci. 2010;46(1):1-17. [DOI: 10.1590/S1984-8250201000010 0002]

Chowdary KPR, Srinivas L. Mucoadhesive drug delivery systems: A review of current status. Indian Drugs 2000;37(9):400-6.

Clark MA, Hirst BH, Jepson MA. Lectin-mediated mucosal delivery of drugs and microparticles. Adv. Drug Deliv. Rev. 2000;43(2-3):207-23. [DOI: 10.1016/S0169-409X(00)00 070-3]

Dharmendra S, Surendra JK, Sujata M, Ashish P, Shweta S. Mucoadhesive drug delivery system: A review. Int. J. Pharm. Biol. Arch. 2012;3(6):1287-91.

Dutta PK, Dutta J, Tripathi VS. Chitin and chitosan: mucoadhesive dosage forms have a high potential of being useful means of delivering drugs to the body. Moreover, current use of mucoadhesive polymers to increase contact time for a wide variety of drugs and routes of administration has shown dramatic improvement in both specific therapies and more general patient compliance. Hence mucoadhesive polymers can be used as means of improving drug delivery through different routes like gastrointestinal, nasal, ocular, buccal, vaginal and rectal. Many potential mucoadhesive systems are being investigated which may find their way into the market in near future.

Chemistry, properties and applications. J. Sci. Ind. Res. 2004:63:20-31.

Efentakis M, Peponaki C. Formulation study and evaluation of matrix and three-layer tablet sustained drug delivery systems based on carbopol with isosorbite mononitrate. AAPS PharmSciTech 2008;9(3):917-23. [DOI: 10.1208/s1 2249-008-9084-2]

Eouani C, Piccerelle Ph, Prinderre P, Bourret E, Joachim J. In-vitro comparative study of buccal mucoadhesive performance of different polymeric films. Eur. J. Pharm. Biopharm. 2001;52(1):45-55. [DOI: 10.1016/S0939-6411 (01)00146-1]

Fan H, Dash AK. Effect of cross-linking on the in vitro release kinetics of doxorubicin from gelatin implants. Int. J. Pharm. 2001;213(1-2):103-16. [DOI: 10.1016/S0378-51 73(00)00651-7]

Fattahi A, Petrini P, Munarin F, Shokoohinia Y, Golozar MA, Varshosaz J, Tanzi MC. Polysaccharides derived from tragacanth as biocompatible polymers and gels. J. Appl. Poly. Sci. 2013;129(4):2092-2102. [DOI: 10.1002/APP.38 931].

Fikentscher H, Herrle K. Polyvinylpyrrolidone. Modern plastics 1945;23:157.

Gandhi RE, Robinson JR. Bioadhesion in drug delivery. Ind. J. Pharm. Sci. 1988;50(3):145-52.

Gibson J, Halliday JA, Ewert K, Robertson S. A controlled release pilocarpine buccal insert in the treatment of Sjogren's syndrome. Br. Dent. J. 2007;202(7):E17.

Hogerstrom H, Edsman K, Stromme M. Low-frequency dielectric spectroscopy as a tool for studying the compatibility between pharmaceutical gels and mucous tissue. J. Pharm. Sci. 2003;92(9):1869-81. [DOI: 10.1002/ jps.10451]

Ishida M, Nambu N, Nagai T. Highly viscous gel ointment containing carbopol for application to the oral mucosa. Chem. Pharm. Bull. (Tokyo) 1983;31(12):4561-4. [DOI: 10.1248/cpb.31.4561]

Khan S, Verma M, Aggarwal G, Kumar SLH. Mucoadhesive drug delivery system: a review. World J. Pharm. Pharm. Sci. 2016;5(5):392-405.

Krupashree KG, Parthiban S, Senthil Kumar GP, Tamizmani T. Approaches to mucoadhesive drug delivery system in oral cavity-a detailed review. Int. J. Res. Pharm. Nano Sci. 2014;3(4): 257-65.

Majithiya RJ, Ghosh PK, Umrethia ML, Murthy RS. Thermoreversible-mucoadhesive gel for nasal delivery of sumatriptan. AAPS PharmSciTech 2006;7(3):67. 
[DOI: 10.1208/pt070367]

Morimoto K, Morisaka K, Kamada A. Enhancement of nasal absorption of insulin and calcitonin using polyacrylic acid gel. J. Pharm. Pharmacol. 1985;37(2):134-6. [DOI: 10.11 11/j.2042-7158.1985.tb05024.x]

Mythri GKK, Kumar MR, Singh SJ. Novel mucoadhesive polymers - A review. J. Appl. Pharm. Sci. 2011;1(8):37-42.

Muthukumaran M, Dhachinamoorthi D, Chandra Sekhar KB, Sriram N. A Reveiw on polymers used in mucoadhesive drug delivery system. Int. J. Pharm Ind. Res. 2011; 1(2):122-7.

Nielsen LS, Schubert L, Hansen J. Bioadhesive drug delivery system. I. Characterization of mucoadhesive properties of systems based on glyceryl mono-oleate and glycerylmono linoleate. Eur. J. Pharm. Sci. 1998;6(3):231-9. [DOI: 10.10 16/S0928-0987(97)10004-5].

Oza KP, Frank SG. Microcrystalline cellulose stabilized emulsion. J. Disper Sci. Technol. 1986;7(5):543-61. [DOI: 10.1080/01932698608943478]

Phaechamud T, Ritthidej GC. Formulation variables influencing drug release from layered matrix system comprising chitosan and xanthan gum. AAPS PharmSciTech 2008;9(3):870-7. [DOI: 10.1208/s12249-0 08-9127-8]

Raghavendra Rao NG, Shravani B, Reddy MS. Overview on Buccal Drug Delivery Systems. J. Pharm. Sci. Res. 2013; 5(4):80-8.

Remuñán-López C, Portero A, Vila-Jato JL, Alonso MJ. Design and evaluation of chitosan/ethylcellulose mucoadhesive bilayered devices for buccal drug delivery. J. Control. Release 1998;55(2-3):143-52. [DOI: 10.1016/S0168-3659 (98)00044-3]
Singh S, Singh S, Bothara SB, Patel R. Pharmaceutical characterization of some natural excipient as potential mucoadhesive agent. T. Ph. Res. 2010;4:91-104.

Saraswathi B, Balaji A, Umashankar MS. Polymers in mucoadhesive drug delivery system-latest updates. Int. J. Pharm. Pharm. Sci. 2013;5(3):423-30.

Satoh K, Takayama K, Machida Y, Suzuki Y, Nakagaki M, Nagai T. Factors affecting the bioadhesive property of tablets consisting of hydroxypropyl cellulose and carboxyvinyl polymer. Chem. Pharm. Bull. (Tokyo) 1989;37(5):1366-8.

Shah D, Gaud RS, Misra AN, Parikh R. Formulation of a water soluble mucoadhesive film of lycopene for treatment of leukoplakia. Int. J. Pharm. Sci. Rev. Res. 2010;2(1):6-10.

Suchaoin W, Pereira de Sousa I, Netsomboon K, Rohrer J, Hoffmann Abad P, Laffleur F, Matuszczak B, BernkopSchnürch A. Mucoadhesive polymers: Synthesis and in vitro characterization of thiolated poly(vinyl alcohol). Int. J. Pharm. 2016;503(1-2):141-9. [DOI: 10.1016/j.ijpharm. 2016.03.006].

Surana AS, Kotecha RK. An overview on various approaches to oral controlled drug delivery system via gastroretention . Int. J. Pharm. Sci. Rev. Res. 2010;2(2):68-72.

Tonnesen HH, Karlsen J. Alginate in drug delivery systems. Drug. Dev. Ind. Pharm. 2002;28(6):621-30. [DOI: 10.108 1/DDC-120003853]

Woertz C, Preis M, Breitkreutz J, Kleinebudde P. Assessment of test methods evaluating mucoadhesive polymers and dosage forms: An overview. Eur. J. Pharm. Biopharm. 2013; 85(3 Pt B): 843-53. [DOI: 10.1016/j.ejpb.2013.0 6.023]. 